\title{
Mutation of $\beta$-catenin in a radiation and estrogen breast cancer model
}

\author{
DEBASISH ROY ${ }^{1}$ and GLORIA M. CALAF ${ }^{2,3}$ \\ ${ }^{1}$ Department of Natural Sciences, Hostos College, The City University of New York, Bronx, NY, USA; \\ ${ }^{2}$ Center for Radiological Research, Columbia University Medical Center, New York, \\ NY, USA; ${ }^{3}$ Instituto de Alta Investigación, Universidad de Tarapacá, Arica, Chile
}

Received July 3, 2014; Accepted September 17, 2014

DOI: $10.3892 /$ ijo.2014.2722

\begin{abstract}
. $\beta$-catenin plays a pivotal role in cell-to-cell adhesion as a transcriptional activator in signal transduction pathways. Potential role of this gene was studied in a radiationand estrogen breast cancer model by analyzing differential expression of associated genes of $\beta$-catenin as E-cadherin and catenins. The aim was to identify whether $\beta$-catenin gene was mutated when associated with other genes as glycogen synthase kinase-3- $\beta$ (GSK-3- $\beta$ ), T-cell factor (TCF) and other extracellular matrix genes related to cell adhesion. Results indicated that $\beta$-catenin gene had increased expression at mRNA and mutation at exon 3 in irradiated and estrogen-treated cell lines when compared to MCF-10F. It was found that $\beta$-catenin and GSK-3- $\beta$ had greater protein expression in the tumorigenic cell line, called Alpha5 and the tumor cell lines, called Tumor 2 than control MCF-10F and non-malignant Alpha3 cell lines. The $\beta$-catenin/GSK-3- $\beta$ complex was identified in non-malignant cell lines such as MCF-10F, Estrogen, Alpha1, Alpha3, and Alpha4 cell lines by immunoprecipitation assays. However, Alpha5 and Tumor2 did not form a complex in this assay. However, $\beta$-catenin/TCF-4 complex was found only in Alpha5 and Tumor2. Immunofluorescent studies confirmed these findings since co-localization in $\beta$-catenin and GSK-3- $\beta$ was only found in MCF-10F and Alpha3 while $\beta$-catenin/TCF-4 was only observed in Alpha5 and Tumor2. It can be concluded that mutation of $\beta$-catenin and its interaction with other associated proteins may be an early event during radiation and estrogen induced progression of human breast carcinogenesis.
\end{abstract}

\section{Introduction}

Breast cancer is a genetically and clinically heterogeneous disease, and the second most frequent cause of cancer death among American women. It accounts for $\sim 30 \%$ of overall

Correspondence to: Dr Debasish Roy, Department of Natural Sciences, Hostos College, The City University of New York, Room \# A-507E, 500 Grand Concourse, Bronx, NY 10451, USA

E-mail: droy@hostos.cuny.edu

Key words: estrogen, radiation, $\beta$-catenin, breast cancer cancer deaths among women $(1,2)$. Epidemiological data indicate that women exposed to ionizing radiation such as radiation therapy, X-ray diagnosis, A-bomb exposure had increased risk of breast cancer incidence compared to normal population (3). The action of radiation on DNA is damaging and consequently a mutagen, thus widely considered to be the basis for its action as a carcinogen (4).

The progression of disease follows a complex multi-step process that depends on various exogenous (socioeconomic situation, diet, breast irradiation, oral contraception, geography etc.) and endogenous (hormonal imbalances and family history of breast cancer) factors that modulate the transformation of human epithelial cells to a neoplastic stage (5). Recent experimental models also suggest that the process of carcinogenesis can be driven by abnormal interactions between cells and their microenvironment (6). Thus, in addition to causing DNA damage, radiation exposure also alters key regulators of multi-cellular organization, which potentially disrupt the normal intercellular communications and can promote neoplastic progression in susceptible cells.

Recent progress in cancer research has shown the importance of $\beta$-catenin, a molecule that plays pivotal roles in cell-to-cell adhesion and as a transcriptional activator in Wnt/Wg signal transduction pathway $(7,8)$. The Wnts are a family of highly conserved, secreted glycoproteins, which have been implicated in stroma-epithelial interactions in the breast and in neoplastic and benign breast disease $(9,10)$. The Wnt signaling pathway plays a critical role in organogenesis and dysregulation of this pathway can contribute to tumorigenesis $(11,12)$. Wnt signaling via cytoplasmic $\beta$-catenin plays a central role and critically control other Wnt responsive genes during development and homeostasis (13).

The intracellular protein $\beta$-catenin remains as a critical downstream factor in this pathway and plays an important role in intercellular adhesion by linking the cytoplastic domain of cadherins to $\alpha$-catenin, which anchors the adhesion complex to the cytoskeleton (14). It also mediates the interactions between cadherins and other transmembrane receptor protein, such as the epidermal growth factor receptor. Due to this interaction, the cadherin-catenin complex becomes a target for regulatory signals that govern cellular adhesiveness and motility (15). These two functions of $\beta$-catenin, E-cadherin binding and signal transduction are interrelated (16). 
The neoplastic transformation of human breast epithelial cell lines in vitro represents a successful model for obtaining step-by-step knowledge on the molecular and cellular alterations that may contribute to the tumorigenic mechanisms. There are few human cell culture models available to study the mechanism of radiation carcinogenesis $(17,18)$. Therefore, to assess the effect of ionizing radiation, particularly of high-LET (linear energy transfer) radiation, on the progression of human breast carcinogenesis, a model system was used consisting of irradiated, transformed and tumorigenic MCF-10F cell lines treated with high-LET radiation (19). We have already reported the involvement of c-Ha-ras oncogene and differential expression of a series of other oncogene/tumor suppressor genes in this context $(20,21)$. Expression of various oncoproteins related to different stages of neoplastic alterations was also identified in this system $(22,23)$. The present study was undertaken to identify whether cell adhesion molecules were involved in transformation induced by radiation and estrogen in a breast cancer model.

\section{Materials and methods}

Cell lines. An established radiation-induced breast carcinogenesis model was used (19). This spontaneously immortalized breast epithelial cell line MCF-10F (24) retain all the characteristics of normal epithelium in vitro, including anchorage-dependence, non-invasiveness and nontumorigenic in the nude mice (19). Cell lines were cultured on Dulbecco's modified Eagle's media (DMEM) as described previously. The breast cancer model consisted of the following cell lines: i) control: MCF-10F; ii) MCF-10F treated with $17 \beta$-estradiol (E) $\left(10^{-8} \mathrm{M}\right)$ (Sigma Chemical Co., St. Louis, MO, USA), exposed to iii) single dose $60 \mathrm{cGy}$ of $\alpha$ particle named Alpha1 (60 cGy); iii) single dose $60 \mathrm{cGy}$ and treated with E, named Alpha2 (60 cGy plus E); iv) double doses of $60 \mathrm{cGy}$ named Alpha3 (60/60 cGy) that was anchorage-independent and non-tumorigenic in nude/SCID mice; v) double dose of $60 \mathrm{cGy}$ of $\alpha$ particle and treated with E, named Alpha4 (60/60 cGy plus E); vi) double dose of 60 cGy of $\alpha$ particle and treated with $\mathrm{E}$ before and after with radiation, named Alpha5 (60 cGy plus E/60 cGy plus E), that was anchorageindependent and formed tumors in nude/SCID mice, named Tumor 2 cell line. Phenotypic characteristics of these cell lines and their genetic alterations including differentially expressed genes were previously described (20-23).

Isolation and purification of total RNA and mRNA. Total RNA was isolated from control MCF-10F and experimental cell lines with TRIzol reagent (Invitrogen Corp., Long Island, NY, USA). Each sample comprising $500 \mu \mathrm{g}$ of total RNA was treated with $5 \mu \mathrm{l}$ of DNAse I (10 U/ $\mu \mathrm{l})$ (Roche Pharm., Indianapolis, IN, USA) for $60 \mathrm{~min}$ at $37^{\circ} \mathrm{C}$. Then $10 \mathrm{X}$ Termination Mix $(0.1 \mathrm{M}$ EDTA, pH 8.0 and $1 \mathrm{mg} / \mathrm{ml}$ glycogen) (Clontech, CA, USA) was used to stop the reaction. Each sample was then purified following established procedure $(20,25)$. The amount of purified RNA sample was measured by a spectrophotometer (the ratio of absorbance reading at 260/280 $\mathrm{nm}$ and then electrophoresed on denaturing formaldehyde/agarose/ethidium bromide gel, to check its quality and purity from proteins and free nucleotides. Each sample $(500 \mu \mathrm{g})$ of purified total RNA was subjected to polyA ${ }^{+}$RNA analysis with Oligotex mRNA Purification kit (Qiagen Inc., Valencia, CA, USA). PolyA RNA was used following standard procedure (25).

Northern blot analysis of $\beta$-catenin $m R N A$. Total RNA $(500 \mu \mathrm{g})$ was treated with $5 \mu \mathrm{l}$ of DNAse I (10 U/ $\mu \mathrm{l})$ (Roche Pharm.) for $60 \mathrm{~min}$ at $37^{\circ} \mathrm{C}$. RNA was extracted and precipitated using $7.5 \mathrm{M}$ ammonium acetate, $\mathrm{pH} 5.2$ (25). A sample of $0.5-1 \mu \mathrm{g}$ of total RNA was used for 1st-strand cDNA synthesis with the Advantage $^{\mathrm{TM}}$ RT For- PCR kit (Clontech) using oligo(dT) $)_{18}$ and random hexamer primers. Then $100 \mathrm{ng}$ of the 1st-strand cDNA synthesis product was used for carrying out RT-PCR reactions using gene specific primers. The PCR amplified products were labeled by using respective primers and Biotin-16-UTP as well as RT cocktail to generate the probes and be used for Northern hybridization analysis. One $\mu \mathrm{g}$ of mRNA was electrophoresed in a $1 \%(\mathrm{w} / \mathrm{v})$ agarose-formaldehyde gel and transferred to a nylon membrane (Hybond-N, Amersham-Pharmacia Biotech, Piscataway, NJ, USA). RNA transfer was confirmed by visualization of ethidium bromide-stained RNA under UV light. Blots were UV cross-linked and stored at $4^{\circ} \mathrm{C}$ until hybridization. Human $\beta$-actin control amplifier set probe was also used in northern hybridization to confirm their similar expression in all samples (25). The blot was then exposed to Kodak $\mathrm{X}$-OMAT AR film at $-80^{\circ} \mathrm{C}$ for $24 \mathrm{~h}$. The intensity was assayed by densitometric scanning (Molecular Dynamics) (20).

Isolation of DNA. All cell cultures were treated with $1 \mathrm{ml}$ of lysis buffer $(100 \mathrm{mM} \mathrm{NaCl}, 20 \mathrm{mM}$ Tris- $\mathrm{HCl} \mathrm{pH} 8.0,25 \mathrm{mM}$ EDTA pH 8.0,0.5\% sodium dodecyl sulfate) with $200 \mathrm{mg} / \mathrm{ml}$ of proteinase $\mathrm{K}$ and RNAse $(100 \mu \mathrm{g} / \mathrm{ml})$, and incubated overnight at $37^{\circ} \mathrm{C}$ with constant gentle agitation (26). Then they were purified following two extractions with a phenol:chloroform (1:1) mixture and the aqueous layer was adjusted to $0.75 \mathrm{M}$ ammonium acetate and DNA was spooled from two volumes of $100 \%$ ethanol, dried and dissolved in TE buffer $(10 \mathrm{mM}$ Tris-HCl pH 8.0, 1 mM EDTA pH 8.0) as described (25).

$\beta$-catenin mutation assay. To screen for mutations in exon 3 of the $\beta$-catenin gene, a portion of that exon was amplified from genomic DNA from all cell lines using the following primer pairs: forward (F) 5'-ATTTGATGGAGTTGGACATGGC-3' and reverse (R) 5'-GAGGAAGAGGATGTGGATACCTCC-3' (27). Amplified DNA fragments were first purified by electrophoresis on 1\% agarose-TAE gel (Life Technologies Inc., Grand Island, NY, USA) and eluted with $100 \mu \mathrm{l}$ of elution buffer from the QIAquick gel extraction kit (Qiagen Inc.) (25). Sequencing was done using the same $\beta$-catenin primers in an automated sequencer ABI PRISM 3100 Genetic Analyzer (Applied Biosystems/Hitachi, Foster City, CA, USA). Each and every fragment was sequenced at least three times to rule out contamination and PCR fidelity artifacts.

Immunoprecipitation and immunoblotting. Whole cell extracts were prepared using a lysis buffer containing $20 \mathrm{mM}$ Tris- $\mathrm{HCl}$ (pH 7.8), $140 \mathrm{mM} \mathrm{NaCl}, 1$ mM EDTA, 0.5\% NP40, $1 \mathrm{mM}$ phenylmthylsulfonyl fluoride, and complete protease inhibitors mixture (Boehringer-Mannheim, Roche, Germany). Cells were allowed to grow in the presence of $10^{-8} \mathrm{M}$ DHT for $24 \mathrm{~h}$ before protein extraction. Cell lysates were passed several 
times through a 30.5-gauge needle to disrupt the nuclei. Protein extract $(\sim 400 \mu \mathrm{g})$ was washed four times with $0.5 \mathrm{ml}$ of lysis buffer, boiled for $5 \mathrm{~min}$, and analysed in $8 \%$ Tris-glycine acrylamide gel. After electrophoresis, proteins were transferred to nitrocellulose membranes using a semidry blotter (Bio-Rad, USA). Blots were probed and was incubated with the primary antibodies of mouse $\beta$-catenin (E5; sc7963), rabbit GSK-3- $\beta$ (H76; sc 9166), and goat TCF-4 (C19; sc8632) (Santa Cruz, Biotechnology Inc., Santa Cruz, CA, USA) at a 1:500 dilution overnight at $4^{\circ} \mathrm{C}$ followed by a secondary antibody conjugated to horseradish peroxidase (1:1000). Detection was by the ECL method (Amersham, Arlington Heights, IL, USA) (28).

Protein expression by immunocytochemistry. Exponentially growing cells were plated on a glass chamber slide (Nunc Inc., Naperville, IL, USA) as previously described at a density of $1 \times 10^{4}$ cells in $1 \mathrm{ml}$ of medium $(29,30)$. The experiments were repeated three times with similar passages. The primary mouse antibody $\beta$-catenin (E5; sc7963), rabbit GSK-3 $\beta$ (H76; sc 9166) and goat TCF-4 (C19; sc8632) (Santa Cruz Biotechnology Inc.) were used for protein expression determination at a 1:500 dilution overnight at $4^{\circ} \mathrm{C}$. The secondary antibody used was Rhodamine conjugated secondary antibody (Jackson ImmunoResearch Lab., West Grove, PA, USA) at a 1:1,000 dilution. Slides were mounted with Vectashield mounting media (Vector Laboratories, Burlingame, CA, USA). Cells were quantified as previously described $(29,30)$ and viewed on Zeiss Axiovert 100 TV microscope (Carl Zeiss, Thornwood, NY, USA) using a 40x 11.3 NA objective lens equipped with a laser scanning confocal attachment (LSM 410 Carl Zeiss). To excite the fluorescent secondary antibody fluorescent images were collected by argon/krypton mixed gas laser (488 nm). Composite images were generated using Adobe Photoshop, 7.0 Program. Protein expression was determined by the relative staining intensity of the control and experimental cell lines. Such computer program gave the area and the intensity of the staining of the cells present in the cells. The number of immunoreactive cells per sample (30 cells/field) was counted in 5 randomly selected microscopy fields. Statistical analysis was done with the F-test (randomized block) and comparisons between groups with the Bonferroni-t-test with significance at P-value of $<0.05(29,30)$.

cDNA expression array. GE Array Q Series Human Extracellular Matrix (ECM) and Cell Adhesion array membranes were used in these studies (SA Biosciences, Bethesda, MD, USA) and tested for control MCF-10F and Tumor 2 cell lines. These arrays were designed to profile gene expression of a panel of 96 key genes important for cell-cell and cell-matrix interactions compose of trans-membrane molecules, and other adhesion molecules that included basement membrane, extracellular matrix and collagens. Each of these genes was amplified by polymerase chain reaction (PCR) with gene-specific primers to generate 200- to 600-bp products. Approximately $100 \mathrm{ng}$ of each PCR product was spotted in quadruplicate onto a positively charged membrane. Each GE Array Q series membrane was spotted with a negative control of pUC18 DNA, blanks and housekeeping genes, including $\beta$-actin, GAPDH, cyclophilin $\mathrm{A}$ and ribosomal protein L13A (20).
Synthesis of $c D N A$ probes from $m R N A$. The purified mRNAs were used for the synthesis of cDNA probes with Biotin-16dUTP (Roche Pharm.). Annealing mixture was prepared by mixing 1.0-5.0 $\mu \mathrm{g}$ of mRNA with $3 \mu \mathrm{l}$ of Buffer A (GE primer mix) (SA Biosciences) and the final volume was adjusted to $10 \mu l$. The mixture was then incubated in a preheated thermal cycler at $70^{\circ} \mathrm{C}$ for $3 \mathrm{~min}$, cooled to $42^{\circ} \mathrm{C}$ and kept at that temperature for $2 \mathrm{~min}$. Then $10 \mu \mathrm{l}$ of RT cocktail was prepared by mixing $4 \mu \mathrm{l}$ of $5 \mathrm{X}$ buffer $\mathrm{BN}$ [for $50 \mu \mathrm{l} 10 \mathrm{X}$ buffer, add $1 \mu \mathrm{l}$ of $1 \mathrm{M}$ DTT and $50 \mu \mathrm{l}$ of 10X dNTP mix (5 mM dATP, dCTP, dGTP and $500 \mu \mathrm{M}$ dTTP)], $2 \mu \mathrm{l}$ of Biotin-16-UTP, $2 \mu \mathrm{l}$ of RNase-free $\mathrm{H}_{2} \mathrm{O}, 1 \mu \mathrm{l}$ of RNase inhibitor (Promega Corp., Madison, WI, USA) and $1 \mu \mathrm{l}$ of MMLV reverse transcriptase (Promega Corp.). RT cocktail was then warmed at $42^{\circ} \mathrm{C}$ for $1 \mathrm{~min}$ and slowly mixed with $10 \mu \mathrm{l}$ of pre-warmed annealing mixture. The incubation continued for $90 \mathrm{~min}$ at $42^{\circ} \mathrm{C}$ and then labeled cDNA probe was denatured by heating for $5 \mathrm{~min}$ at $94^{\circ} \mathrm{C}$, and quickly chilled on ice. mRNA was isolated and purified from the cell lines, and cDNA probes were prepared and hybridized to the respective membranes. Experiments using the same mRNA preparation were repeated three times, and measurable, median-normalized expression values of each gene were compared to avoid false-positive signals (20).

Differential hybridization of cDNA expression array. Each array membrane was pre-wetted with $5 \mathrm{ml}$ of de-ionized water and incubated at $60^{\circ} \mathrm{C}$ for $5 \mathrm{~min}$. It was then replaced with $2 \mathrm{ml}$ of pre-warm $\left(60^{\circ} \mathrm{C}\right)$ GEA pre-hybridized solution (GEAprehyb) with a heat-denatured sheared salmon sperm DNA at a final concentration of $100 \mu \mathrm{g} / \mathrm{ml}$ ) (SA Biosciences) and mixed gently for few seconds. Pre-hybridization was continued at $60^{\circ} \mathrm{C}$ for $1-2 \mathrm{~h}$ with continuous gentle agitation. Approximately $0.75 \mathrm{ml}$ solution of GEAprehyb was prepared by adding the entire volume of denatured cDNA probe onto GEAprehyb solution and kept at $60^{\circ} \mathrm{C}$. Then GEAprehyb solution was replaced by GEAhyb solution and hybridization continued overnight at $60^{\circ} \mathrm{C}$ with continuous gentle agitation. Subsequently, array membranes were washed twice in wash solution 1 ( $2 \mathrm{X}$ sodium chloride sodium citrate and $1 \%$ sodium dodecyl sulfate) at $60^{\circ} \mathrm{C}$ for 15 min each with gentle agitation and then twice with solution 2 ( $0.1 \mathrm{X}$ sodium chloride sodium citrate and $0.5 \%$ sodium dodecyl sulfate) at $60^{\circ} \mathrm{C}$ for $15 \mathrm{~min}$ each with gentle agitation. To assess the reproducibility of the hybridization array assays, pair-wise comparisons between array data sets for each cell line was tested by repeated hybridization and the mRNAs prepared in different lots were analyzed in scatter plots with multiple regression $(20,31)$. In each case, expression levels of $95 \%$ of the genes had repeated values that were within 2-fold (20).

Chemiluminescent detection of $c D N A$ probes. After discarding the last wash, $2 \mathrm{ml}$ of GEA blocking solution was added to each membrane and incubated for $40 \mathrm{~min}$ at room temperature with continuous agitation. Then binding buffer was prepared by diluting alkaline phosphatase-conjugated streptavidin (AP) with 1X buffer F (SuperArray, Bethesda, MD, USA) in a 1:7,500 dilution. GEA blocking solution was replaced by $2 \mathrm{ml}$ of binding buffer and incubated for $10 \mathrm{~min}$ with continuous but gentle agitation. Then membrane was washed for 4 times with $4 \mathrm{ml}$ of $1 \mathrm{X}$ binding buffer $\mathrm{F}$ for $5 \mathrm{~min}$ in each washing 


\section{Extracellular matrix and cell adhesion array}

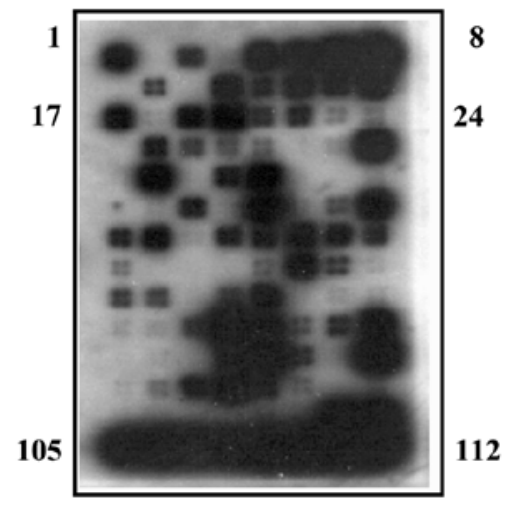

MCF-10F

\section{Gene name}

\begin{tabular}{|l|}
\hline E-cadherin \\
$\alpha$-Catenin \\
$\alpha$-Catenin-like 1 \\
$\beta$-Catenin \\
$\delta 1$-Catenin \\
ס2-Catenin \\
\hline
\end{tabular}

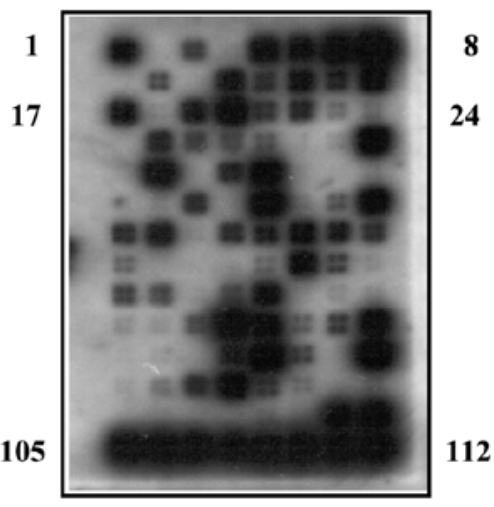

Tumor2

$\begin{aligned} 7 & \rightarrow \text { Z13009 } \\ 14 & \rightarrow \text { NM_001903 } \\ 15 & \rightarrow \text { NM_003798 } \\ 16 & \rightarrow \text { NM_001904 } \\ 17 & \rightarrow \text { AF062343 } \\ 18 & \rightarrow \text { U96136 }\end{aligned}$

12
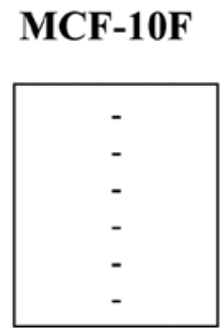

\section{Tumor2}

\begin{tabular}{l} 
Down-regulated \\
Down-regulated \\
Down-regulated \\
Up-regulated \\
Down-regulated \\
No change \\
\hline
\end{tabular}

Figure 1. GE Array Q Series Human Extracellular Matrix and Cell Adhesion array membranes used (SA Biosciences). cDNA expression array containing extracellular matrix and cell adhesion genes were used in control MCF-10F and Tumor2 cell line.

and rinse twice with $3 \mathrm{ml}$ of rinsing buffer $\mathrm{G}$ (SuperArray). The membrane was covered with $1.0 \mathrm{ml}$ of CDP-Star chemiluminescent substrate and incubated at room temperature for 2-5 min. It was then exposed to X-ray film (Kodak Bio Max MS Film; Kodak Corp., Rochester, NY, USA) with corresponding intensifying screen at room temperature for multiple exposures of 1-5 min.

Quantification of array hybridization. Quantification of hybridization signals on the expression array membranes was carried out by exposing the autoradiographic film in a densitometric scanner (model 300A; Molecular Dynamics, Sunnyvale, CA, USA). It was then estimated both with the Image Quant (Molecular Dynamics) and Scan Analyze program (Eisen Lab., California University, CA, USA). Volume quantification was performed by calculating the volume under the surface created by a three-dimensional plot of pixel locations and pixel values as described (20,31). All raw signal intensities were corrected for background by subtracting the signal intensity of a negative control or blank. Results were also normalized to that of a housekeeping gene. These corrected, normalized signals can then be used to estimate the relative abundance of particular transcripts. To delineate the potential signal interference between adjacent strong hybridization signals, equal-sized ellipses were drawn around each signal area (hybridization spots) using software (Image Quant/Scan Alyze) and was then separately scanned and compared with housekeeping genes so the chances of interference between adjacent strong hybridization signals were minimized. Normalization of the expression levels of different housekeeping genes from multiple autoradiographic exposures between different hybridization experiments were done by taking the average signals of each of the housekeeping genes. Data from high intensity spots were chosen for further use. Median background was subtracted, and signals that were $<2.0$-fold above background level were considered too low to accurately measure and were omitted from the analysis. Signals for each individual gene were also normalized to the geometric mean of the expression level of that gene across the set of membranes being compared. Mean signals were calculated from quadruplicate measurable spots, or if three of the four spots were measurable. The change in the fold indicated whether a gene exhibits increased, decreased, or unchanged expression based on statistical criteria (31).

\section{Results}

Differential expression of genes associated with adhesion such as $\beta$-catenin, $\alpha$-catenin, $\delta$-catenins, E-cadherin were identified through a cDNA expression array and comparing the control MCF-10F and a tumor cell line as Tumor2 as seen in Fig. 1. Results showed downregulation of genes as E-cadherin and catenins in Tumor 2 cell line compared to control. $\beta$-catenin gene was upregulated. Table I shows the detection of mutated sequence of $\beta$-catenin gene of exon 3 from position 227 to 298 . These studies indicated mutation in Alpha5 and Tumor 2 cell lines as at positions $228(\mathrm{G} \rightarrow \mathrm{C}), 245(\mathrm{G} \rightarrow \mathrm{T} / \mathrm{C}), 252(\mathrm{~T} \rightarrow \mathrm{C} / \mathrm{A})$, 266 $(\mathrm{T} \rightarrow \mathrm{A}), 276(\mathrm{C} \rightarrow \mathrm{T}), 283(\mathrm{C} \rightarrow \mathrm{A}), 285(\mathrm{~A} \rightarrow \mathrm{C}), 288(\mathrm{C} \rightarrow \mathrm{A}), 290$ $(\mathrm{T} \rightarrow \mathrm{C}), 293(\mathrm{~T} \rightarrow \mathrm{C} / \mathrm{A})$. 
Table I. Mutated sequences of $\beta$-catenin gene at exon 3 in a breast cancer model.

\begin{tabular}{ll}
\hline MCF-10F & CAGAATGCAGTTTGAGAACTAAAAAGTTAGTGTCTAATAGTTTAAATAAAATGTTGCGGTGAACAAA \\
MCF10F+E & CAGAATGCACTTTTGAGAACTAAAAATTTAGTGCCTAATAGTTTAAAAAAAATGTTGCGGTGAACAAA \\
& ACATACCCATAG \\
Alpha1 & CAGAATGCAGTTTTGAGAACTAAAAATTTAGTGACTAATAGTTTAAAAAAAATGTTGTGGTGAACAAA \\
& ACATACCCATAG \\
Alpha2 & CAGAATGCACTTTTGAGAACTAAAAATTTAGTGACTAATAGTTTAAAAAAAATGTTGTGGTGAACAA \\
& AACATACCCATAG \\
Alpha3 & CAGAATGCAGTTTTGAGAACTAAAAATTTAGTGACTAATAGTTTAAAAAAAATGTTGTGGTGAAAAAA \\
& AAATACCCATAG \\
Alpha4 & CAGAATGCACTTTTGAGAACTAAAAATTTAGTGACTAATAGTTTAAAAAAAATGTTGTGGTGAAAAAA \\
& AAATACCCATAG \\
Alpha5 & CAGAATGCACTTTGAGAACTAAAAATTTAGTGACTAATAGTTTAAATAAAATGTTGTGGTGAAAACA \\
& AAACACCCATAG \\
Tumor2 & CAGAATGCAGTTTTGAGAACTAAAAACTTAGTGACTAATAGTTTAAATAAAATGTTGTGGTGAAAACA \\
& AAACACACATAG
\end{tabular}

No change from 1 to 227 and from 298 to 360. Mutation from 227 to 298.
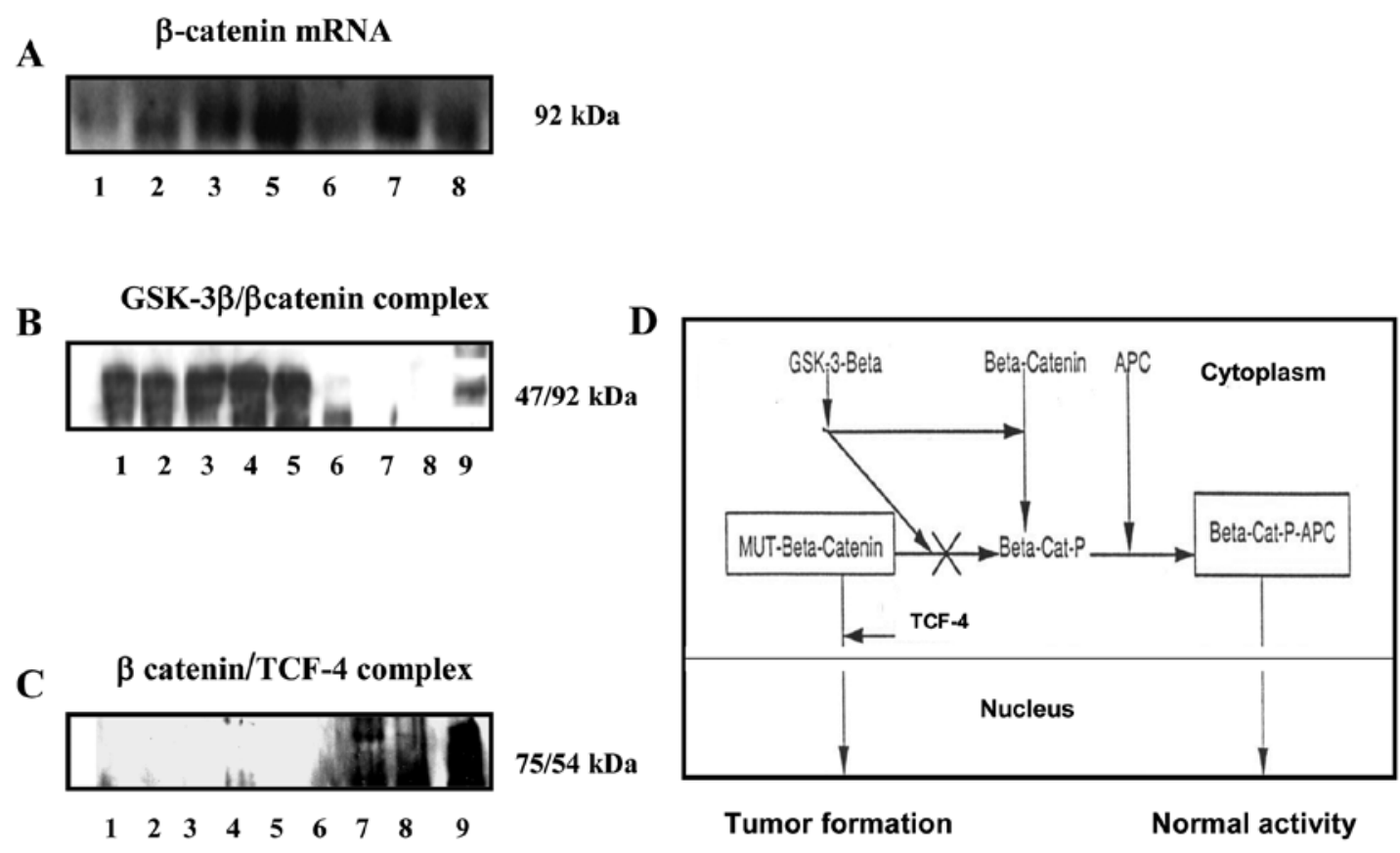

1: MCF-10F; 2: MCF-10F+Estrogen (E);
3: Alpha1; 4: Alpha2; 5: Alpha3, 6: Alpha4; 7:
Alpha5; 8: Tumor2; 9: Marker
P: Beta-CatP:Beta catenin phosphorilated

Figure 2. Immunoprecipitation assay with the following cell lines. 1, MCF-10F; 2, MCF-10F+Estrogen (E); 3, Alpha1; 4, Alpha2; 5, Alpha3; 6, Alpha4; 7, Alpha5; 8, Tumor2; 9, Marker. (A) $\beta$-catenin mRNA of MCF-10F, Estrogen, Alpha1, Alpha2, Alpha3, Alpha4, Alpha5 and Tumor2 cell lines. (B) $\beta$-catenin and GSK-3- $\beta$ complex formed by immunoprecipitation in MCF-10F, Estrogen, Alpha1, Alpha2, Alpha3, Alpha4 cell lines. (C) $\beta$-catenin/TCF-4 complex formed by immunoprecipation in Alpha5 and Tumor 2 cell cell lines. (D) Proposed scheme for $\beta$-catenin, GSK-3- $\beta$ and $\beta$-catenin/TCF- 4 interaction in a breast cancer model.

Fig. $2 \mathrm{~A}$ corresponds to $\beta$-catenin mRNA expression in all cell lines of this model when compared to control MCF-10F. The $\beta$-catenin gene was amplified in all irradiated- and estrogen-treated cell lines when compared to MCF-10F. Fig. $2 \mathrm{~B}$ shows a $\beta$-catenin/GSK-3- $\beta$ complex formed in non-malignant cell lines as MCF-10F, Estrogen, Alpha1, 


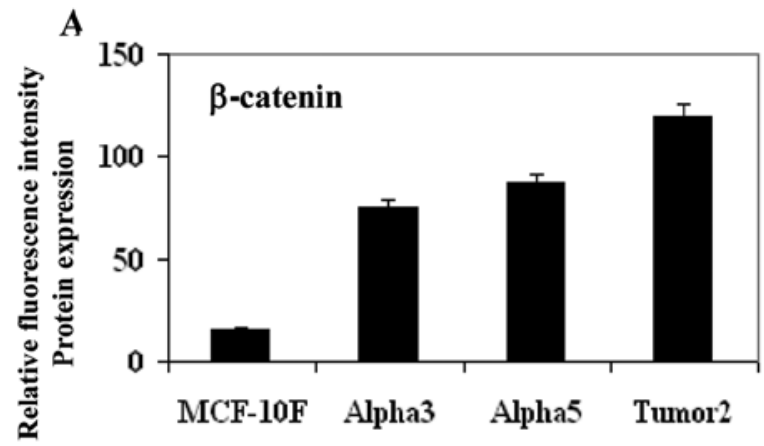

B

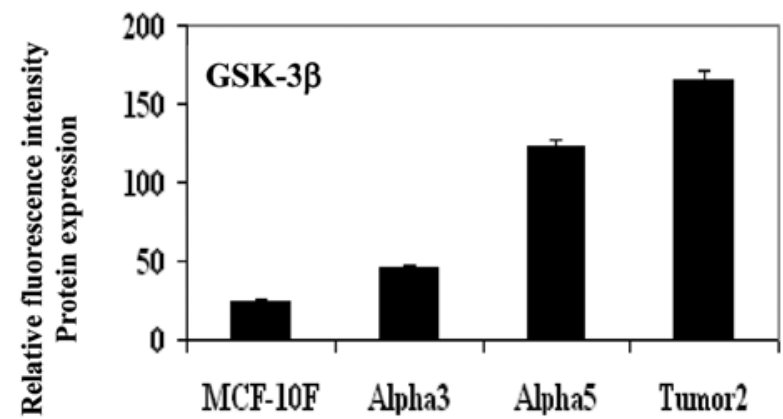

Figure 3. Graphs that show the relative fluorescent intensity of protein expression of (A) $\beta$-catenin and (B) GSK-3- $\beta$ in MCF-10F, Alpha3, Alpha5 and Tumor2 cell lines.
Alpha3, and Alpha4 cell lines by immunoprecipitation assays. However, Alpha5 and Tumor2 did not form a complex in this assay. On the other hand, the $\beta$-catenin/TCF was only found by co-precipitation in Alpha5 and Tumor2 (Fig. 2C). Fig. 2D shows a schematic flow chart of the possible interaction of $\beta$-catenin with GSK-3- $\beta$ and $\beta$-catenin/TCF in cytoplasm and nucleus in different cell lines in this particular breast cancer model.

Protein expression of GSK-3- $\beta$ and $\beta$-catenin by immunofluorescent studies. Measurement of relative fluorescence intensity of protein expression indicated that $\beta$-catenin and GSK-3 $\beta$ had greater gene expression in the tumorigenic cell line Alpha5 and Tumor 2 tumor cell line than control MCF-10F and non-malignant Alpha3 cell lines. Fig. 3 shows a graph of relative fluorescent intensity of $\beta$-catenin (Fig. 3A) and GSK-3- $\beta$ (Fig. 3B), respectively. Representative images of the corresponding graphs of $\beta$-catenin and GSK-3- $\beta$ protein expression in MCF-10F, Alpha3, Alpha5 and Tumor2 are shown in Fig. 4A and B, respectively. Fig. 4C shows the fluorescence images that indicated that there was co-localization of $\beta$-catenin and GSK-3- $\beta$ in the non-malignant cell lines MCF-10F and Alpha3, but not in Alpha5 and Tumor2 cell lines. On the other hand, there was only $\beta$-catenin/TCF-4 co-localization in Alpha5 and Tumor2 cell lines (Fig. 4D).

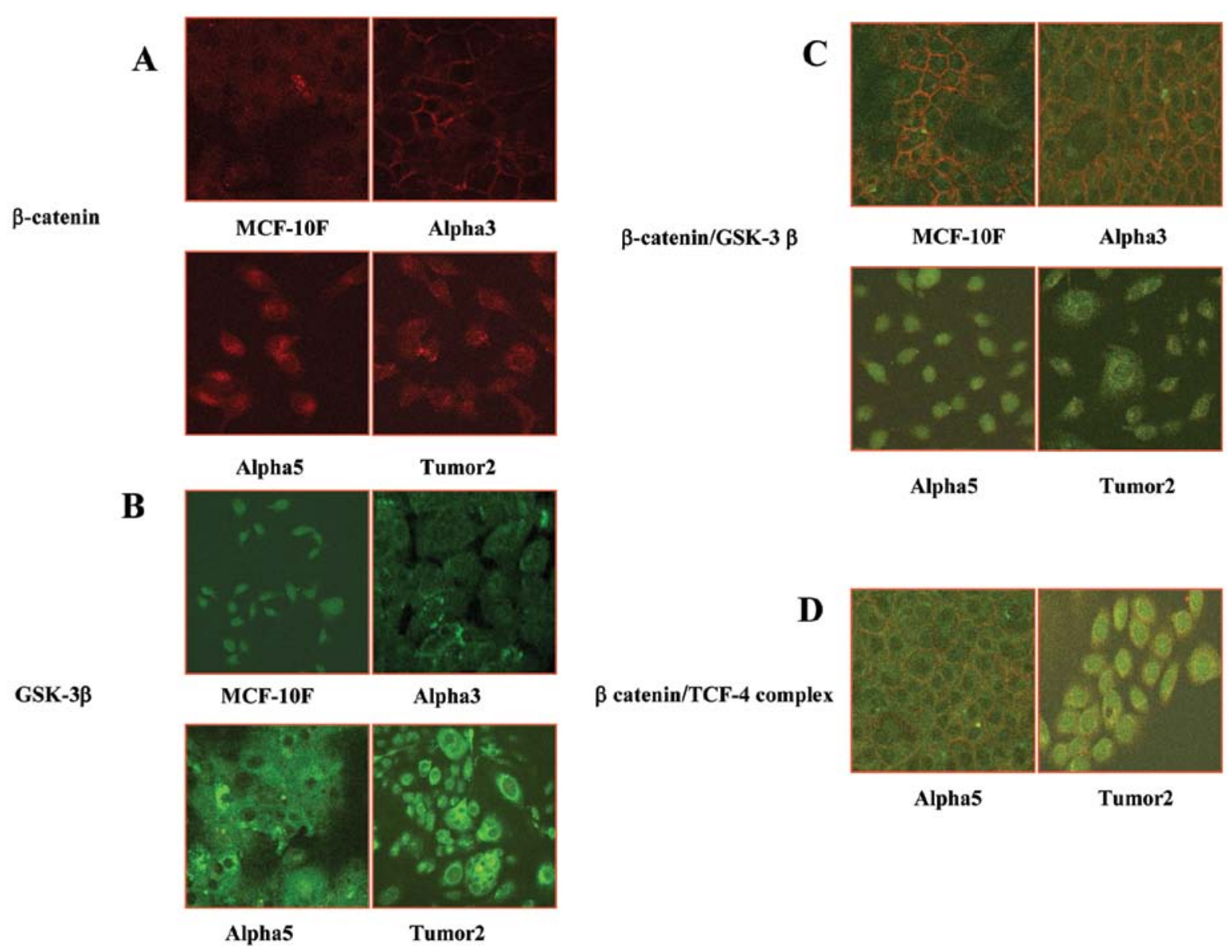

Figure 4. Representative images of (A) $\beta$-catenin and (B) GSK-3- $\beta$ in MCF-10F, Alpha3, Alpha5 and Tumor 2 cell lines, respectively. (C) Co-localization of $\beta$-catenin/GSK-3- $\beta$ in MCF-10F and Alpha3. (B) Lack of co-localization in $\beta$-catenin/GSK-3- $\beta$. (D) Co-localization of $\beta$-catenin/TCF-4 in Alpha5 and Tumor 2 cell lines. 


\section{Discussion}

Gene regulation of adhesion molecules is very important as are all catenins and E-cadherin in cancer progression. Differential expression of genes associated with adhesion such as $\beta$-catenin, $\alpha$-catenin, $\delta$-catenins and $E$-cadherin, were identified and compared in Tumor2, a tumor and MCF-10F, a control cell line. Mutation and amplification of $\beta$-catenin gene in this process has a vital role. $\beta$-catenin and GSK-3- $\beta$ were highly expressed in the tumorigenic cell line Alpha5 and Tumor 2 but not in the control MCF-10F and the non-malignant Alpha 3 cell lines. These two genes are important in the cancer progression since $\beta$-catenin/GSK-3- $\beta$ complex was identified in the non-malignant cell lines as MCF-10F, estrogen, Alpha1, Alpha3, and Alpha4 cell lines. Lack of co-localization in the tumorigenic cell lines Alpha5 and Tumor2 corroborated the crucial role of genes in the signaling pathway.

The $\beta$-catenin/TCF complex observed only in Alpha5 and Tumor 2 confirmed the significance of genes in this cancer progression. A schematic flow chart is proposed to suggest a possible action of mutated $\beta$-catenin with GSK-3- $\beta$ or TCF- 4 applied in this particular breast cancer model. Authors have shown that regulation of $\beta$-catenin turnover requires the $\mathrm{NH}_{2}$-terminal region of the protein containing the potential GSK-3- $\beta$ phosphorylation site, since phosphorylated $\beta$-catenin is targeted for degradation. Loss of control of intracellular $\beta$-catenin levels through mutation or to any other associated factors has been proposed as an important oncogenic step in tumorigenic progression (32).

It has been proposed that mutated $\beta$-catenin gene at exon 3 probably prevents phosphorylation of GSK-3- $\beta$ (33). Inhibition of this activity is probably due to unbound $\beta$-catenin to accumulate in the cytoplasm and translocate into the nucleus by activating TCF-dependent transcription that occurs during tumorigenic progression. The TCF protein is a weak activator of transcription, therefore the binding of $\beta$-catenin induces a significant increase in transcriptional activity.

It can be concluded that it is very interesting to find a complex formed between $\beta$-catenin and GSK-3- $\beta$ only in the non-tumorigenic cell lines and GSK-3- $\beta$ complex only in the tumor ones compared to MCF-10F. These findings corroborated the role of $\beta$-catenin/TCF in mammary cancer which acts as a switch to determine cell fate and promote cell survival and proliferation at several stages of mammary gland development and cancer progression $(34,35)$. It is known that in the absence of a Wnt signal the $\beta$-catenin levels are low in the cells due to the association with a cytoplasmic protein complex comprised of GSK-3- $\beta$, APC and axin (27). It has been shown that phosphorylation of $\beta$-catenin by GSK-3- $\beta$ leads to proteosomal degradation of $\beta$-catenin. Wnt stimulation inhibits GSK-3- $\beta$, resulting in stabilization of $\beta$-catenin translocation to the nucleus, and activation of target genes and enhancement of its association with the TCF family of transcription factors, can result in transcriptional activation of multiple target genes (11).

It has been also been reported that deregulation of $\beta$-catenin leads to constitutive formation of the $\beta$-catenin-Tcf/LEF complex and altered expression of Tcf target genes such as, Wnt/Tcf target genes in cancer cells (36-38). Altered expression was also noted in various adenocarcinomas in breast, gastric and prostate cancer (39-41). Recently, translocation and altered expression of $\beta$-catenin were also reported in irradiated-colonic mucosa as well as in colon cancer of mouse mammary progenitor cells $(42,43)$. The present report also provides evidence that of $\beta$-catenin signaling pathway may play a role during progression in radiation and estrogen induced human breast cancer. It can be concluded that mutation of $\beta$-catenin and its interaction with other associated proteins may be an early event during radiation and estrogen induced human breast cancer progression.

\section{Acknowledgements}

The support given by FONDECYT no. 1120006 (GMC) and MINEDUC-Universidad de Tarapacá, Chile (GMC) and assistance given by Richard Ponce-Cusi is greatly appreciated.

\section{References}

1. Greenlee RT, Murray T, Bolden S and Wingo PA: Cancer Statistics. CA Cancer J Clin 50: 7-33, 2000.

2. American Cancer Society (ACS): Breast cancer facts and figures, 2013-2014 (www.cancer.org/research/cancerfactsstatistics/breastcancer-facts-figures)

3. Park CC, Henshall-Powell RL, Erickson AC, Talhouk R, Parvin B, Bissell MJ and Barcellos-Hoff MH: Ionizing radiation induces heritable disruption of epithelial cell interactions. Proc Natl Acad Sci USA 100: 10728-10733, 2003.

4. Grosovsky AJ: Radiation-induced mutations in unirradiated DNA. Proc Natl Acad Sci USA 96: 5346-5347, 1999.

5. Loeb LA: Mutator phenotype may be required for multistage carcinogenesis. Cancer Res 51: 3075-3079, 1991.

6. Bissell MJ and Radisky D: Putting tumours in context. Nat Rev Cancer 1: 46-54, 2001.

7. Bullions LC and Levine AJ: The role of beta-catenin in cell adhesion, signal transduction and cancer. Curr Opin Oncol 10: 81-87, 1998.

8. Willert K and Nusse R: Beta-catenin: a key mediator of Wnt signaling. Curr Opin Genet Dev 8: 95-102, 1998.

9. Huguet EL, McMahon JA, McMahon AP, Bicknell R and Harris AL: Differential expression of human Wnt genes 2, 3, 4, and 7B in human breast cell lines and normal and disease states of human breast tissue. Cancer Res 54: 2615-2621, 1994.

10. Lejeune S: Wnt5a cloning, expression, and up-regulation in human primary breast cancers. Clin Cancer Res 1: 215-222, 1995.

11. Wodarz A and Nusse R: Mechanisms of Wnt signaling in development. Annu Rev Cell Dev Biol 14: 59-88, 1998.

12. Taipale $\mathbf{J}$ and Beachy PA: The Hedgehog and Wnt signalling pathways in cancer. Nature 411: 349-354, 2001.

13. Polakis P: Wnt signaling and cancer. Genes Dev 14: 1837-1851, 2000.

14. Gumbiner BH: Signal transduction of beta-catenin. Curr Opin Cell Biol 7: 634-640, 1995.

15. Kinch MS: Tyrosine phosphorylation regulates the adhesions of ras-transformed breast epithelia. J Cell Biol 130: 461-471, 1995.

16. Fagotto F, Funayama N, Gluck U and Gumbiner BM: Binding to cadherins antagonizes the signaling activity of beta-catenin during axis formation in Xenopus. J Cell Biol 132: 1105-1114, 1996.

17. Thraves PJ, Salehi Z, Dritschilo A and Rhim JS: Neoplastic transformation of immortalized human epidermal keratinocytes by ionizing radiation. Proc Natl Acad Sci USA 87: 1174-1177, 1990.

18. Hei TK, Piao CQ, Willey JC, Thomas S and Hall EJ: Malignant transformation of human bronchial epithelial cells by radonsimulated alpha-particles. Carcinogenesis 15: 431-437, 1994.

19. Calaf GM and Hei TK: Establishment of a radiation- and estrogen-induced breast cancer model. Carcinogenesis 21: 769-776, 2000.

20. Roy D, Calaf GM and Hei TK: Profiling of differentially expressed genes induced by high linear energy transfer radiation in breast epithelial cells. Mol Carcinog 31: 192-203, 2001. 
21. Roy D, Calaf GM and Hei TK: Allelic imbalance at 11p15.5-15.4 correlated with c-Ha-ras mutation during radiation-induced neoplastic transformation of human breast epithelial cells. Int J Cancer 103: 730-737, 2003.

22. Calaf GM, Roy D and Hei TK: Immunochemical analysis of protein expression in breast epithelial cells transformed by estrogens and high linear energy transfer (LET) radiation. Histochem Cell Biol 124: 261-274. 2005.

23. Calaf G and Hei TK: Oncoprotein expression in human breas epithelial cells transformed by high-LET radiation. Int J Rad Biol 77: 31-40, 2001.

24. Soule HD, Vazguez J, Long A, Albert S and Brennan M: A human cell line from a pleural effusion derived from a breast carcinoma. J Natl Cancer Inst 51: 1409-1413, 1973.

25. Sambrook J and Green MR: Molecular Cloning - A Laboratory Manual. Cold Spring Harbor Laboratory Press, Cold Spring Harbor, NY, 1989.

26. Gross-Bellard M, Oudet P and Chambon P: Isolation of highmolecular-weight DNA from mammalian cells. Eur J Biochem 36: 32-38, 1973 .

27. Morin PJ: Beta-catenin signaling and cancer. Bioessays 21: 1021-1030, 1999

28. Truica CI, Byers S and Gelmann EP: $\beta$-catenin affects androgen receptor transcriptional activity and ligand specificity. Cancer Res 60: 4709-4713, 2000.

29 Calaf GM and Roy D: Gene and protein expressions induced by $17 \beta$-estradiol and parathion in cultured breast epithelial cells Mol Med 13: 255-265, 2007.

30. Calaf GM, Alvarado ME and Hei TK: $\beta$-catenin is associated with breast cancer progression in vitro. Int J Oncol 26: 913-921, 2000.

31. Lui WM, Mei R, Di X, et al: Analysis of high density expression microarrays with signed-rank call algorithms. Bioinformatics 18 : 1596-1599, 2002.

32. Cowin P, Rowlands TM and Hatsell SJ: Cadherins and catenins in breast cancer. Curr Opin Cell Biol 17: 499-508. 2005.

33. Miller JR and Moon RT: Signal transduction through $\beta$-catenin and specification of cell fate during embryogenesis. Genes Dev 10: 2527-2539, 1996
34. Hatsell S, Rowlands T, Hiremath M and Cowin P: Beta-catenin and Tcfs in mammary development and cancer. J Mammary Gland Biol Neoplasia 8: 145-158, 2003.

35. Gebeshuber CA, Sladecek S and Grunert S: Beta-catenin/LEF-1 signalling in breast cancer-central players activated by a plethora of inputs. Cell Tissues Organs 185: 51-60, 2007.

36. He TC, Sparks AB, Rago C, et al: Identification of c-MYC as a target of the APC pathway. Science 281: 1509-1512, 1998.

37. Tetsu $\mathrm{O}$ and McCormick F: Beta-catenin regulates expression of cyclin D1 in colon carcinoma cells. Nature 398: 422-426, 1999.

38. Crawford HC, Fingleton B, Gustavson MD et al: The PEA3 subfamily of Ets transcription factors synergizes with betacatenin-LEF-1 to activate matrilysin transcription in intestinal tumors. Mol Cell Biol 21: 1370-1383, 2001.

39. Pierceall WE, Woodard AS, Morrow JS, Rimm D and Fearon ER: Frequent alterations in E-cadherin and alpha- and beta-catenin expression in human breast cancer cell lines. Oncogene 11: 1319-1326, 1995.

40. Jawhari A, Jordan S, Poole S, Browne P, Pignatelli M and Farthing MJ: Abnormal immunoreactivity of the E-cadherincatenin complex in gastric carcinoma: relationship with patient survival. Gastroenterology 112: 46-54, 1997.

41. Paul R, Ewing CM, Jarrard DF and Isaacs WB: The cadherin cell-cell adhesion pathway in prostate cancer progression. $\mathrm{Br} \mathrm{J}$ Urol 79: 37-43, 1997.

42. Nakashima M, Meirmanov S, Matsufuji R, Hayashida M, Fukuda E, Naito S, Matsuu M, Shichijo K, Kondo H, Ito M, Yamashita S and Sekine I: Altered expression of beta-catenin during radiation-induced colonic carcinogenesis. Pathol Res Pract 198: 717-724, 2002.

43. Woodward WA, Chen MS, Behbod F, Alfaro MP, Buchholz TA and Rosen JM: WNT/beta-catenin mediates radiation resistance of mouse mammary progenitor cells. Proc Natl Acad Sci USA 104: 618-623, 2007. 